\title{
O método alegórico e o interacionismo sociodiscurso, uma aproximação
}

\author{
The Allegorical Method and sociodiscursive interaction, \\ an approach
}

João Carlos Domingues dos Santos Rodrigues

\section{Resumo}

Este trabalho objetiva uma aproximação entre o Método Alegórico utilizado pelos Padres da Igreja nos primeiros séculos do cristianismo e o Interacionismo Sociodiscursivo (ISD), para isto empreenderá análise de uma homilia de Ambrósio de Milão. Assumindo por regra a prática pedagógica de Jesus, os Padres da Igreja desenvolveram um método que valorizava as capacidades linguísticas e cognitivas de seus interlocutores visando a interpretação dos textos bíblicos e do ensino da fé, adotando a linguagem como ferramenta ordenadora do real e os gêneros textuais como aqueles pelos quais os homens interagem com o divino e entre si, como salientaram Jaeger e Bento XVI. Princípios estes muito próximos daqueles observados na prática do ISD. Visando explicitar como o Método Alegórico assume princípios comuns aos de Bakhtin e Vygotsky, os mesmos do ISD, serão analisados o conteúdo e a estrutura de uma homilia presente na obra "Sobre os Sacramentos", bem como a situação de produção (lato sensu) na qual inscrevem-se Ambrósio, seus interlocutores e os demais Padres da Igreja, além dos pressupostos culturais e filosóficos marcantes ao método desenvolvido por ele. Espera-se, a partir dessa aproximação, tanto uma revitalização da Alegoria Patrística quanto um enriquecimento do ISD e de seu campo de influência.

Palavras Chave: Patrística. Método Alegórico. Pedagogia. Interacionismo Sociodiscursivo. 


\begin{abstract}
This work aims at an approximation between the Allegorical Method used by the Church Fathers in the first centuries of Christianity and the Sociodiscursive Interactionism (ISD), for this purpose to undertake analysis of a homily by Ambrose of Milan. In the pedagogical practice of Jesus, the Fathers of the Church developed a method that valued the linguistic and cognitive capacities of their interlocutors aiming at the interpretation of biblical texts and the teaching of the faith, adopting language as an ordering tool of the real and textual genres such as those by which men interact with the divine and with each other, as Jaeger and Benedict XVI emphasized. Principles that are very close to those observed in ISD practice. With the purpose of explaining how the Allegorical Method assumes principles common to those of Bakhtin and Vygotsky, the same as those the of ISD, the content and structure of a homily present in the works "About the Sacraments", will occur, as well as the situation of production (lato sensu) in which Ambrose, his interlocutors and the other Fathers of the Church are enrolled in addition to the cultural and philosophical striking the method developed by them. It is expected, from this approach, both a revitalization of the Patristic Allegory and an enrichment of the ISD and its field of influence.
\end{abstract}

Keywords: Patristic. Allegorical Method. Pedagogy. Sociodiscursive Interaction

\title{
Introdução
}

Empreender-se-á um estudo acerca do método utilizado por Ambrósio de Milão em vista da interpretação da Bíblia e do ensino da doutrina cristã, supondo uma aproximação entre esse método e o das Teorias do Letramento, mais precisamente do Interacionismo Sociodiscurso (ISD). O objeto de análise consistirá no método, de linguagem alegórica, materializado na prática pedagógica (catequética) de Ambrósio de Milão.

Para tanto, num primeiro momento, apresentaremos os elementos que compõem, em perspectiva ampla, o momento histórico e eclesial no qual Ambrósio está inserido, o período Patrístico. Na sequência explicitaremos os pressupostos culturais e filosóficos deste período histórico, com destaque para as influências recebidas por Ambrósio. Em um terceiro momento 
apresentaremos aqueles que são os princípios basilares do método utilizado pelo ISD, já apontando para uma aproximação com o método ambrosiano. Por fim, realizaremos uma análise da prática pedagógica de Ambrósio de Milão na obra "Catequeses Quaresmais", demonstrando sua relação com os pressupostos aceitos e defendidos pelo método do ISD.

A hipótese que levantamos é de que assim como Jesus se utilizava de uma compreensão de linguagem e de ensino que leva em conta as capacidades linguísticas e cognitivas para a promoção do desenvolvimento dos indivíduos, também os primeiros líderes formados a partir dos ensinamentos dos Apóstolos, os Padres da Igreja, a seu modo, se valeram desses princípios e constituíram uma prática pedagógica muito próxima daquela proposta pelo ISD, que, no contexto do ensino, tem seu foco nos estudantes, em suas capacidades comunicativas, e no potencial enunciativo presente no texto e no gênero pelo qual ele se apresenta. Enfatizamos a coerência de tal aproximação pelo testemunho de Clemente de Alexandria, ${ }^{1}$ que, referindo-se a Jesus, o chama de "o Pedagogo", aquele que por alegorias nos ensina sobre as coisas do alto, concedendo-nos, gradativamente, acesso à salvação.

\section{Situação de produção no Período Patrístico}

O movimento das primeiras comunidades em ultrapassarem o isolamento e a exclusividade da Judeia, dirigindo-se para as regiões circunvizinhas, unificadas pela língua e cultura grega, iniciou um processo de inculturação da fé cristã que exigiu empenho das lideranças das novas comunidades, encontrando na filosofia uma aliada perfeita - pois para eles "a religião cristã (era) a expressão íntegra e definitiva da verdade que a filosofia grega atingira imperfeita e parcialmente". ${ }^{2}$

Nesse contato, "todo um mundo de conceitos, categorias de pensamento, metáforas (foram) herdadas, e conotações sutis entram no pensamento cristão". ${ }^{3}$ Para além de uma passagem de movimento rural para um movimento citadino, essa transformação requereu uma alteração no modo de transmissão da mensagem de Jesus, da modalidade oral para escrita, mas que também exigiu uma adaptação conceitual da doutrina. Usando a linguagem e suas ferramentas, os primeiros líderes das comunidades cristãs não buscavam promover um relacionamento com as Escrituras tomando-as em seu significado "objetivo",

${ }^{1}$ CLEMENTE DE ALEJANDRÍA, El Pedagogo, I, Cap. 84.

${ }^{2}$ ABBAGNANO, N., Patrística, p. 746.

${ }^{3}$ JAEGER, W., Cristianismo Primitivo e Paideia Grega, p. 13. 
mas no sentido que o texto possuía para "o hoje" histórico, teológico e/ou espiritual no qual era lido. ${ }^{4}$

O período pós apostólico que tem início no século I da era cristã, tendo a "Didaqué" (datada do ano 90 d.C.), como um de seus marcos, é chamado de Período Patrístico ou simplesmente Patrística. Geograficamente, é possível encontrar representantes da Patrística e sua influência por toda a extensão daquilo que foi o Império Romano, desde os países do oriente médio, norte da África, até a Península Ibérica. Frente à sua realidade sociocultural, os representantes deste período assumiram uma postura dialógica, "capaz de assimilar pensamentos e formas expressivas dos adversários para apresentá-los, mudados pelo espírito, como seus", ${ }^{5}$ possibilitando o diálogo entre a religião e outras áreas do conhecimento, enriquecendo o discurso religioso e atualizando as temáticas religiosas às necessidades de seus ouvintes.

A Patrística abarca pensadores, na sua grande maioria clérigos, do oriente (Cirilo de Jerusalém, Orígenes, João Crisóstomo etc.) e do ocidente (Ambrósio, Agostinho, Irineu de Lyon, Tertuliano etc.), caracterizados pela plena comunhão com a Igreja, pela defesa e propagação da ortodoxia da fé, e pelo reconhecimento de uma vida de fé exemplar, da parte dos fiéis. ${ }^{6}$ Para a igreja primitiva, eles também foram responsáveis por fornecer os primeiros e principais instrumentos hermenêuticos para o cristianismo (dentre os quais está a compilação dos textos que compõem a Bíblia).

Não atuando como meros repetidores dos Apóstolos e da Tradição, mas desenvolvendo uma "refinada técnica", 7 a influência e importância desses personagens é tamanha que a doutrina católica afirma não ser possível interpretar as Escrituras "contra o consenso unânime dos Padres (da Igreja)". Por este motivo, essas figuras emblemáticas são chamadas, quer por cristãos católicos, protestantes e/ou evangélicos, de "Santos Padres" ou "Pais/Padres da Igreja"9 - de onde deriva o termo Patrística.

A divisão mais comum para os Padres da Igreja quanto à língua, ambiente cultural, espaço de atuação pastoral, escritos, dentre outros, é: "Padres Gregos" (Clemente de Alexandria; Atanásio de Alexandria; João Crisóstomo;

${ }^{4}$ GARGANO, I., A metodologia exegética dos Padres, p. 184.

${ }^{5}$ SIMONETTI, M.; PRINZIVALLI, E., Storia della letteratura cristiana antica, p. 15, tradução nossa.

${ }^{6}$ DROBNER, H. R., Manual de Patrología, p. 18-19.

${ }^{7}$ GARGANO, I., A metodologia exegética dos Padres, p. 181.

${ }^{8}$ DF II.

${ }^{9}$ Reale e Antisere assim explicam o conceito "Padres da Igreja": "são todos aqueles homens que contribuíram de modo determinante para construir o edifício doutrinário do cristianismo, que a Igreja acolheu e sancionou" (REALE, G.; ANTISERE, D., História da Filosofia, p. 400). 
Cirilo de Alexandria, Máximo, o Confessor, dentre outros); e "Padres Latinos" (Irineu de Lião, Tertuliano, Leão Magno, Gregório Magno, Agostinho, Ambrósio de Milão, Jerônimo, dentre outros). Dentro do grupo dos "Padres Gregos", destacam-se os "Padres Capadócios": Basílio de Cesareia, Gregório Nazianzeno, Gregório de Nissa, Pedro de Sebaste, dentre outros. ${ }^{10}$

Por abranger um período de aproximadamente sete séculos, vários foram os contextos políticos e sócio-históricos nos quais os Padres da Igreja se viram inseridos, passando desde a perseguição dos cristãos pelos imperadores romanos, especialmente Diocleciano no século III; pela liberação do culto cristão, pelo Édito de Milão, de Constantino, em 313; pela proclamação do cristianismo como religião oficial do Império Romano por Teodósio, em 380, pelo Édito de Tessalônica; como a queda do Império Romano do Ocidente, em 476; e até o auge do Império Bizantino, com Justiniano, no século VI.

Os séculos IV e V são considerados o período áureo da Patrística, tanto no oriente quanto no ocidente. Sendo dada aos cristãos a liberdade de culto e posteriormente tendo alcançado o status de religião oficial, estruturas mais complexas começam a ser organizadas e implementadas, e a unidade nos princípios da fé e na liturgia começaram a ganhar relevância política para a manutenção da pax romana. Assim, estes séculos são os séculos nos quais ocorrem os Concílios de Niceia I (325), Constantinopla I (381) e Éfeso (431), que tiveram a função de dirimir conflitos teológicos e doutrinários, delimitando o credo e fechando o cânone da Bíblia. Neste cenário, os Padres da Igreja tiveram papel decisivo. ${ }^{11}$

$\mathrm{O}$ encerramento do período Patrístico varia no oriente e no ocidente. No oriente assume-se o fim da Patrística com a morte de João Damasceno, no século VIII. Já no ocidente, são as mortes de Gregório Magno e Isidoro de Sevilha, no século VII, o seu marco final.

\section{Formação discursiva de Ambrósio de Milão e do Método Alegórico}

Dentre os Santos Padres, Ambrósio, embora seja um Padre Latino, mantém estreitos vínculos com a formação discursiva de alguns Padres Gregos e Capadócios, com destaque para Basílio de Cesareia e Orígenes (além de Fílon de Alexandria) - autores que cooperaram para enriquecer o então raso conhecimento da literatura cristã no período que foi eleito Bispo de Milão, aos 35 anos. ${ }^{12}$

\footnotetext{
${ }^{10}$ ORLANDIS, J., Historia de la Iglesia, p. 54.

${ }^{11}$ COMBY, J., Para ler a História da Igreja, p. 107-115.

${ }^{12}$ SIMONETTI, M.; PRINZIVALLI, E., Storia della letteratura cristiana antica, p. 453.
} 
O método alegórico desenvolvido por Ambrósio é herdeiro do proceder exegético-hermenêutico da Escola de Alexandria (especialmente de Orígenes), utilizando a simbologia e a riqueza espiritual dessa escola para desenvolver seus ensinamentos ${ }^{13}$ - o método alexandrino aplicou à interpretação das Sagradas Escrituras técnicas gregas utilizadas na interpretação dos textos de Homero e Hesíodo; o resultado foi a sistematização de uma técnica hermenêutica bastante próxima daquela desenvolvida por Paulo Apóstolo (haja vista suas influências estoicas), capaz de ir além do sentido literal, acessando um sentido espiritual, dito "mais profundo". ${ }^{14}$

Embora sendo judeu, Fílon de Alexandria forneceu relevante contribuição para a estruturação do Método Alegórico. Em seus escritos, reconhece a existência de dois sentidos para a leitura: a) o sentido literal; b) o sentido oculto ou alegórico. Embora o "sentido literal" seja tratado como em grau inferior ao "sentido alegórico", já que superficial e imediato, apenas símbolo, enquanto este outro seria mais claro, profundo, conseguido apenas com cuidado, Fílon dá importância ao "sentido literal" como integrante do percurso que deve ser feito até que se possa atingir o "sentido alegórico", e salienta que assim agindo seriam evitadas resistências à leitura alegórica: "Se o devido cuidado for dado à forma literal, mais claro será a compreensão do sentido oculto, do qual aquela forma é um símbolo, e ademias as reprovações e censuras da maioria das pessoas serão evitadas". ${ }^{15} \mathrm{O}$ "sentido literal" funcionaria apenas como invólucro exterior do "sentido alegórico" (aquele seria como o "corpo", enquanto este como a "alma" ${ }^{16}$ ), requerendo do leitor um trabalho hermenêutico e uma particular disposição de espírito para acessar os múltiplos significados ocultos por detrás das palavras. ${ }^{17}$

Orígenes, reconhecendo o homem como formado por "corpo, alma e espírito" (1Ts 5,23), falará em três sentidos possíveis ao texto bíblico: o sentido literal como aquele que está na semântica imediata das palavras e conceitos (no nível do corpo); o sentido moral é aquele que toma as passagens bíblicas compreendo-as em relação com os mandamentos e com o comportamento concreto do cristão (no nível da alma, psíquico); o sentido místico, por seu caráter universal e coletivo, é o que possibilita entrar em contato com o Texto Sagrado lendo-o sob um ponto de vista escatológico, viabiliza a leitura do

\footnotetext{
${ }^{13}$ FIGUEIREDO, F. A., La Vita de la Iglesia Primitiva, p. 257-258.362.

${ }^{14}$ QUASTEN, J., Patrología - Hasta el concilio de Nicea, p. 216-318.

${ }^{15}$ FILÓN DE ALEJANDRÍA, Sobre la migración de Abraham, n. 93.

${ }^{16}$ FILÓN DE ALEJANDRÍA, Sobre la migración de Abraham, n. 93.

${ }^{17}$ FILÓN DE ALEJANDRÍA, Sobre las habituales intrigas de lo peor contra lo mejor, n. 155.
} 
Antigo Testamento como em referência profética a Cristo (tipologia), ou propicia ler o conjunto dos textos bíblicos como paradigma das verdades de fé apontando para o Cristo e para os sacramentos da Igreja (é o nível do espiritual). ${ }^{18}$

Pelo fato de que "o que está na letra é figura de certos mistérios, e imagem das realidades divinas", ${ }_{19}$ para que se possa atingir "as realidades divinas", segundo Orígenes, seria necessário antes passar pela compreensão das coisas que nos são mais evidentes, apesar de superficiais, o texto escrito com suas marcas características e com as escolhas lexicais e semânticas feitas pelo autor sagrado - sendo realidades estas apenas sombras daquelas. ${ }^{20}$

Devia a essas características do Método Alegórico, a leitura e interpretação das Escrituras é vista por Ambrósio como uma referência para a fé vivida no cotidiano, uma ferramenta capaz de iluminar os critérios das escolhas e julgar segundo a verdade - "É preciso que na leitura da Escritura nasça para nós o sol, que antes não existia" ${ }^{21}$-, fazendo o homem e a mulher "imitadores" das ações de Deus, configurados à Jesus. Mas, para isto, demandava que a leitura ultrapasse os limites da letra do texto e acessasse sentidos mais profundos (segundo o Espírito). Tal prática estaria ao alcance de todos, contanto que orientada pela fé verdadeira. ${ }^{22}$

Talvez devido a esta orientação e a seu desejo de levar as Escrituras ao maior número possível de pessoas, boa parte de suas obras estão relacionadas ao contexto litúrgico-sacramental. Não se fechando ao mistério, ${ }^{23}$ mas, ao mesmo tempo, apresentando as Escrituras e a fé de um modo simples,$^{24} \mathrm{o}$ Método Alegórico procura levar o iniciante cristão (catecúmeno),

${ }^{18}$ DROBNER, H. R., Manual de Patrología, p. 158-160; QUASTEN, J., Patrología - Hasta el concilio de Nicea, p. 406.

Salientamos que embora uma das caraterísticas do sentido alegórico seja de que ele "es siempre nuevo y estructurante de la vida del cristiano" (FIGUEIREDO, F. A., La Vita de la Iglesia Primitiva, p. 207), há, porém, críticas ao modo como Orígenes, por vezes, o empregou. Em algumas ocasiões nas quais o sentido literal do texto foi totalmente negado, Orígenes acabou por empreender interpretações fantásticas e exageradas de trechos das Escrituras, degenerando em um misticismo, motivo pelo qual o método mistagógico foi posto em questionamento e deixado de lado por um bom tempo, sendo mais recentemente retomado (QUASTEN, J., Patrología Hasta el concilio de Nicea, p. 403-405).

${ }^{19}$ ORÍGENES, Tratado sobre os Princípios, Prefácio, §8.

${ }^{20}$ FIGUEIREDO, F. A., La Vita de la Iglesia Primitiva, p. 220.

${ }^{21}$ AMBRÓSIO, Examerão, Cap IV, $§ 1,1$.

${ }^{22}$ FIGUEIREDO, F. A., La Vita de la Iglesia Primitiva, p. 272-374.

${ }^{23}$ BOGAZ, A. S.; COUTO, M. A.; HANSEN, J. H., Patrística, caminhos da tradição cristã; PADOVESE, L., Introdução à Teologia Patrística.

${ }^{24}$ BENTO XVI, PP., Os Padres da Igreja, p. 69. 
gradativamente, a abrir os olhos ao mistério da fé, tudo por meio de explicações e ensinamentos capazes de integrar a vida (em todas as suas dimensões: intelectual, afetiva, comunitária) ao espiritual. ${ }^{25}$ No percurso engendrado por este método não é possível dizer que haja uma perca ou um déficit entre a interpretação realizada por um iniciante ou por alguém já iniciado e/ou experiente, pois segundo seus pressupostos a interpretação deve levar em conta as capacidades do intérprete, expandindo-se e aperfeiçoando-se na mesma medida e intensidade do desenvolvimento do leitor ${ }^{26}$ - e segundo Basílio de Cesareia, ${ }^{27}$ "os participantes da graça do Espírito dela usufruem quanto é possível a sua natureza, não, porém, à medida que ele pode transmiti-la".

Completando o panorama da formação discursiva de Ambrósio de Milão é importante ressaltar que para além da forte oposição que exerceu contra o arianismo, o sabelianismo, o docetismo e o apolinarismo, escrevendo várias obras e proferindo várias homilias objetando essas doutrinas, contribuindo para a difusão da fé de Niceia, o Bispo de Milão também engajou-se na resolução de problemas de ordem social e política, dentre os quais destacamos a prestação de serviço aos mais pobres e a busca pelo reconhecimento do cristianismo como religião oficial do império e de uma separação de competências entre Igreja e Estado - exercendo forte influência sobre os imperadores Teodósio e Graciano. ${ }^{28}$ A atuação de Ambrósio deixou marcas na produção filosófica e teológica não apenas no ocidente cristão, mas é reconhecido como um dos poucos Padres da Igreja que repercutiram também no oriente, tendo suas obras traduzidas para o grego. ${ }^{29}$

\section{Os pressupostos teóricos do ISD}

O Interacionismo Sociodiscursivo, elaborado por Jean-Paul Bronckart, se inscreve em um rol de métodos e práticas pedagógicas que visam o letramento dos indivíduos. $\mathrm{O}$ processo de letramento está ligado à compreensão, por parte do indivíduo, daquele lugar que ele próprio ocupa do mundo e de como se apropria de sua cultura, visando levar este indivíduo a atuar de modo competente no uso social da língua, compreendendo e

${ }^{25}$ BOROBIO, D., Pastoral de los sacramentos, p. 43-44.

${ }^{26}$ SIMONETTI, M.; PRINZIVALLI, E., Storia della letteratura cristiana antica, p. 153.

${ }^{27}$ BASÍLIO DE CESAREIA, Tratado sobre o Espírito Santo, Cap. 9, §22.

${ }^{28}$ QUASTEN, J., Patrología - La edad de oro de la literatura patrística latina, p. 169-171.76177.209-211; DROBNER, H. R., Manual de Patrología, p. 337-340; AGOSTINHO, Confissões, Cap. VI, $\S 3,3$.

${ }^{29}$ DROBNER, H. R., Manual de Patrología, p. 334. 
produzindo textos dos mais diversos gêneros e temas; tornando-o apto a ler um texto em suas entrelinhas, selecionar os recursos linguísticos apropriados a seus objetivos e à circunstância em que o discurso será realizado. Oportunizar o letramento, assim, não seria propriamente ensinar, mas promover que o indivíduo seja capaz de transpor todo seu conhecimento prévio para o mundo das letras, do qual se mantinha distante.

A novidade do método de Bronckart está em conciliar teóricos da educação, da filosofia e da psicologia, propondo um percurso de ensinoaprendizagem que valoriza o estudante, com seus conhecimentos prévios, e reconhece a importância das ferramentas linguísticas e o auxílio dos gêneros discursivos na apropriação de conteúdos novos. Para ele, neste seu processo de dar sentido ao mundo, em sua "atitude comunicativa", o agente produtor do discurso pode valer-se de dois "arquétipos psicológicos", correspondendo a dois mundos discursivos: $:^{30}$ o mundo do narrar e o mundo do expor. O mundo do narrar, encontrando-se em "disjunção" ao mundo ordinário da situação de produção e abarca os gêneros romance, fábula, conto, parábola dentre outros, requerendo do discurso uma ancoragem espaço-temporal. $\mathrm{O}$ mundo do expor encontra-se em "conjunção" ao mundo ordinário da situação de produção, não necessitando de uma ancoragem espaço-temporal, abrangendo os gêneros textuais artigo científico, resenha, ensaio e etc..

Em relação à "situação de produção", tanto o mundo do narrar quanto o do expor podem ser/estar em implicação ou em autonomia. Há implicação com o "ato da produção" quando o discurso traz em si marcas de interação direta com seu destinatário; contrariamente, há autonomia quando essas marcas não são encontradas, utilizadas pelo produtor.

Já os gêneros, esses podem ser classificados $\operatorname{como}^{31}$ primários ou secundários. Os gêneros primários são aqueles aprendidos naturalmente e inscritos na esfera do cotidiano, tendo vínculos imediatos de interação com a realidade; instrumentalizam o indivíduo para a vida em sociedade, permitindo sua atuação efetiva nos mais diversos contextos. Os gêneros secundários, embora mantenham relação estreita com os gêneros primários (mais simples), por surgirem de interações sociais mais complexas, necessitam ser aprendidos por meio da educação formal. Quando fala de tipos textuais, um conceito mais amplo que o de gênero, Bronckart afirma existirem seis protótipos linguísticos, modelos abstratos, que agrupam todos os gêneros discursivos e auxiliam produtor e receptor na construção e compreensão dos textos:

\footnotetext{
${ }^{30}$ BRONCKART, J.-P., Atividade de linguagem, texto e discurso, p. 150-164.

${ }^{31}$ SCHNEUWLY, B.; DOLZ, J., Gêneros orais e escritos na escola, p. 25-31.
} 
sequência narrativa; sequência descritiva; sequência argumentativa; sequência explicativa; sequência dialogal; sequência injuntiva. ${ }^{32}$

Para sua análise metódica da realidade linguística, o ISD nutre-se da teoria de Mikhail Bakhtin, que defende a língua como uma realidade dialógica e polifônica, pois, tanto nossos discursos quanto a interpretação que fazemos do discurso alheio, são sempre baseados em conhecimentos recebidos de outros e por nós reelaborados e manifestos através de gêneros discursivos. Assim, "cada enunciado é um elo da cadeia muito complexa de outros enunciados", 33 abrindo espaço para uma postura responsiva-ativa do leitor, modificando, acrescentando, enriquecendo a si, ao próprio enunciado e a realidade na qual estes estão inseridos. ${ }^{34}$

Ao voltar-se para a compreensão dos mecanismos que os indivíduos utilizam para produzir e reelaborar o conhecimento, a teoria psicopedagógica de Lev Semenovich Vygotsky é uma ferramenta importante para o ISD. Superando o mecanicismo e o biologismo, vê o homem não como mero produto, mas em constante diálogo com o seu meio, constituído pelo modo único com que suas capacidades são articuladas. Por este motivo, Vygotsky salienta a necessidade do reconhecimento desses elementos históricos e individuais como ponto de partida para a prática pedagógica, único modo de criar uma zona de desenvolvimento proximal entre quem ensina e quem aprende. ${ }^{35}$ Neste processo, a linguagem assume posição de destaque, haja vista que é por meio dela que o homem se relaciona socialmente, e ordena a si e ao mundo ${ }^{36}$ é por meio da linguagem que ele estrutura seus pensamentos e responde ativamente ao confrontar-se e ser desafiado pelo novo. ${ }^{37}$

Estruturado a partir dos pressupostos apresentados por Bakhtin e Vygotsky, o ISD propõe uma prática pedagógica que se desenvolva através de uma "sequência didática", de um percurso claro e gradativo, previamente apresentado ao estudante, a ser realizado por ele na companhia de seu mestre, e que, aos poucos, fará com que o estudante se aproprie dos mais variados conhecimentos por meio do reconhecimento das estruturas lógicas e linguísticas desses. O papel do mestre não será apenas de apresentar o conteúdo

\footnotetext{
${ }^{32}$ BRONCKART, J.-P., Atividade de linguagem, texto e discurso, p. 218.

${ }^{33}$ BAKHTIN, M., Estética da Criação Verbal, p. 292.

${ }^{34}$ BAKHTIN, M., Estética da Criação Verbal, p. 295.298.

35 VYGOTSKY, L. S.; LURIA, A. R.; LEONTIEV, A. N., Linguagem, Desenvolvimento e Aprendizagem, p. 18.168-173.

${ }^{36}$ VYGOTSKY, L. S., Pensamento e Linguagem, p. 12-13.

37 VYGOTSKY, L. S.; LURIA, A. R.; LEONTIEV, A. N., Linguagem, Desenvolvimento e Aprendizagem, p. 114.148-149.
} 
novo, mas, inserindo-se no ambiente discursivo dos estudantes e valendo-se dos elementos nele contidos, deverá instigar o estudante, motivá-lo a dar suas próprias respostas, retomando conhecimentos anteriores e apresentando novos problemas, dando exemplos e apontando outros tantos caminhos, ciente de que "embora o processo de empréstimo inspire-se, necessariamente, em modelos existentes, quase nunca acaba em uma cópia integral ou em reprodução exata de um exemplar desse modelo". ${ }^{38}$

\section{Análise da prática ambrosiana e sua relação com o ISD}

Integrando a filosofia como parte importante de sua fé, adotando a "alegoria" como "verdadeiro método de leitura da Bíblia" ${ }^{39}$ e importante recurso didático, e assumindo a mistagogia como percurso pedagógico que conduz e introduz ao mistério, ${ }^{40}$ o Método Alegórico de Ambrósio de Milão não apenas se mantem como modelo de ensino para os cristãos, mas também se aproximam de uma perspectiva bastante moderna sobre a atuação do "educador" e a estruturação dos conteúdos e sequências didáticas diferentemente de algumas teorias de interpretação textual encontrados hoje, que buscam o "sentido original" e o "sentido mais antigo" como sendo os mais verdadeiros, o Método Alegórico tem na "atualidade" a fonte de relevância e veracidade do texto, e no que diz respeito à interpretação da Bíblia, a máxima assumida é de que "se a Escritura tem autoridade, então ela também precisa ter um significado para a atualidade. E a interpretação deve trazê-la à luz". ${ }^{41}$

Nossa compreensão é que as teorias de Bakhtin e Vygotsky (fundamentos do ISD), mesmo sem saber, retomam os princípios por detrás do Método Alegórico quando reiteram não haver "discurso fechado em si" ${ }^{42}$ ou "um 'sentido em si", ,4 e quando destacam que a linguagem e os significados

\footnotetext{
${ }^{38}$ BRONCKART, J.-P., Atividade de linguagem, texto e discurso, p. 102.

${ }^{39}$ REALE, G.; ANTISERE, D., História da Filosofia, p. 400-401.

${ }^{40}$ TABORDA, F., Nas fontes da vida cristã, p. 107.

${ }^{41}$ GUNNEWEG, A. H. J., Hermenêutica do Antigo Testamento, p. 31. Na atualidade, alguns estudiosos denominam a técnica que não busca o sentido literal, tal como a adotada pelos Padres da Igreja, como voltada para o sentido "mais-que-literal", que seria um sentido mais complexo que o literal, múltiplo em significados, de linguagem figurativa, simbólica, mística e/ou espiritual, em suma, um sentido de caráter superior (GABEL, J. B.; WHEELER, C. B., A Bíblia como Literatura, p. 229-231).

${ }^{42}$ ORLANDI, E. P., O que é linguística, p. 62.

${ }^{43}$ BAKHTIN, M., Estética da Criação Verbal, p. 387.
} 
dos signos linguísticos não são imutáveis, devendo passar por constante e contínuo processo de atualização. ${ }^{44}$

Agostinho, falando sobre a estratégia didática por detrás do Método Alegórico e sua aparente falta de objetividade, afirma que "se aprende mais espontaneamente qualquer coisa com a ajuda de comparações" 45 e "se descobre com maior prazer as coisas que se procuram com certa dificuldade". ${ }^{46} \mathrm{O}$ apego à literalidade dos textos, especialmente das Escrituras, é tratado por ele como "a morte da alma", ${ }^{47}$ pois limita a inteligência do homem não a abrindo para as múltiplas possibilidades interpretativas que podem estar escondidas no texto. Seria assumindo que somente Deus é capaz da compreensão perfeita e imediata $^{48}$ e aceitando conviver com a obscuridade de própria condição, que o homem se manteria no importante estado de busca constante, não assumindo uma postura soberba, letárgica ou de fastio.

Reflexão complementar a essa, Vygotsky sistematizou séculos mais tarde. Afirmou que mesmo levando em conta o nível de desenvolvimento efetivo (o que já é dado), o processo de aprendizagem, para que possa ser aproveitado pelo indivíduo, requer um trabalho com o desenvolvimento potencial (com o vir a ser), o desafiando a ir além, ativando novos processos. ${ }^{49}$

Gregório Magno, em sua obra "Regra Pastoral", salienta que "a palavra dos mestres deve ter presente a condição de seus ouvintes, de modo que se adapte às necessidades de cada um [...]. Porque, com frequência, o que é útil a alguns prejudica a outros", ${ }^{50}$ demonstrando uma clara compreensão da existência de diferentes processos de aquisição do conhecimento, os quais podem variar segundo a idade, a condição social e econômica, ou a situação emocional e o sexo, e que devem ser levados em conta no processo pedagógico.

Ao apresentarem suas reflexões sobre a relação que o indivíduo tem para com seu contexto, tanto Vygotsky ${ }^{51}$ quanto Bakthin ${ }^{52}$ reconhecem não haver nível zero no processo de aprendizagem, pois todos os nossos discursos são elaborados a partir dos discursos de outros que nos antecederam, e que acabam

\footnotetext{
${ }^{44}$ VYGOTSKY, L. S., Pensamento e Linguagem, p. 150.

${ }^{45}$ AGOSTINHO, A Doutrina Cristã, II, cap. 6, $\S 8$.

${ }^{46}$ AGOSTINHO, A Doutrina Cristã, II, cap. $6, \S 8$.

${ }^{47}$ AGOSTINHO, A Doutrina Cristã, III, cap. 5, $\S 9$.

${ }^{48}$ AGOSTINHO, A Doutrina Cristã, II, cap. 12, §17.

49 VYGOTSKY, L. S.; LURIA, A. R.; LEONTIEV, A. N., Linguagem, Desenvolvimento e Aprendizagem, p. 103-115.

${ }^{50}$ GREGORIO MAGNO, Regra Pastoral, III, Prologo.

51 VYGOTSKY, L. S.; LURIA, A. R.; LEONTIEV, A. N., Linguagem, Desenvolvimento e Aprendizagem, p. 109.

${ }^{52}$ BAKTIN, M., Estética da Criação Verbal, p. 292.
} 
funcionando como limite, fronteiras para o nosso pensamento. Negar essas influências implicaria em não tornar significativa, e não fazer efetiva qualquer tentativa de superá-las.

Nesta tentativa de fazer acessível as Escrituras aos mais variados públicos, nos mais diversos contextos, os escritos dos Padres da Igreja utilizaram uma rica variedade de gêneros discursivos (algumas delas comuns dentre os mestres gregos ${ }^{53}$ ), dentre as quais temos: cartas; homilias; sermões; ensaios; diálogos filosóficos; parábolas; resenhas; resumos dentre outros. Para nossa análise e exemplificação das potencialidades de aproximação entre o Método Alegórico e o ISD foi escolhido um texto do gênero homilia, presente na obra "Catequeses Quaresmais", de Ambrósio de Milão.

O gênero "homilia", segundo dicionários, manuais e instruções próprias, distingue-se do gênero "sermão", uma distinção que vai além da origem etimológica de cada um. ${ }^{54}$ A homilia é a que tem caráter familiar e informal, ${ }^{55}$ devendo ter como conteúdo motivador ao menos um dos três excertos bíblicos que são lidos na celebração (momento chamado Liturgia da Palavra) - em sua Exortação Apostólica "Evangelii Gaudium”, o Papa Francisco assim se refere à homilia:

A homilia é um retomar este diálogo que já está estabelecido entre o Senhor e o seu povo (na Liturgia da Palavra). Aquele que prega deve conhecer o coração da sua comunidade para identificar onde está vivo e ardente o desejo de Deus e também onde é que este diálogo de amor foi sufocado ou não pôde dar fruto. ${ }^{56}$

Por sua vez, um sermão distingue-se por ser um pronunciamento formal, realizado de uma cátedra ${ }^{57}$ partindo de um tema, uma comemoração, um personagem ao qual se queira dar destaque, como seu conteúdo motivador.

Embora não se apresente uma estrutura definida para o gênero homilia, é possível identificar nesse gênero elementos que o caracterizariam como fazendo parte do rol das sequências argumentativas. A sequência argumentativa apresenta uma estrutura de, basicamente, 4 fases: $1^{\text {a }}$ )

53 JAEGER, W., Cristianismo Primitivo e Paideia Grega, p. 16.

54 Sermão vem da palavra latina sermo, e significa fala, palavra, conversa (SCHÜLER, A., Sermão, p. 423). Homilia é derivada da palavra grega omilein, significando trato, conversa (SCHÜLER, A., Homilia, p. 236).

${ }^{55}$ ROQUETTE, J. I.; FONSECA, J., Homilia, p. 372.

${ }^{56} \mathrm{EG} 137$.

${ }^{57}$ ROQUETTE, J. I.; FONSECA, J., Homilia, p. 372. 
PREMISSAS (constatação inicial); $2^{\mathrm{a}}$ ) ARGUMENTOS (elementos que orientam a uma conclusão provável); $3^{\text {a }}$ ) CONTRA-ARGUMENTOS (promovem uma restrição da orientação argumentativa); $4^{\mathrm{a}}$ ) CONCLUSÃO (integra os efeitos dos argumentos e contra-argumentos).$^{58}$ Entretanto, o gênero homilia pode compreender outras sequências, como a "sequência narrativa", "sequência explicativa" ou a "sequência injuntiva", a depender do tema e do autor. A atitude comunicativa identificada nas homilias, geralmente, coloca-se em uma posição de conjunção ao mundo ordinário da situação de produção, com um discurso pertencente à ordem do expor.

A homilia a ser analisada, encontrara-se no contexto da Liturgia Eucarística do tempo quaresmal, que no período Patrístico era a última etapa em preparação ao batismo para aqueles que pretendiam ingressar na comunidade cristã, isto depois de um longo período de estudo do querigma cristão (o anúncio da Paixão, Morte e Ressurreição de Jesus). Mesmo passados mais de quinze séculos, é possível reconhecer e identificar esses textos como sendo homilias, mas seu diferencial está na utilização do Método Alegórico para a transmissão da mensagem pretendida.

A quarta homilia de Ambrósio sobre "Os Sacramentos" tem por tema motivador uma perícope da Carta aos Hebreus ( $\mathrm{Hb}$ 9,2-7), relativa a um comentário acerca da vara de Aarão e sua eleição como sacerdote, o primeiro sacerdote do povo judeu, da antiga aliança. Localizada no contexto da liturgia quaresmal, a homilia se insere na preparação dos catecúmenos para a recepção dos sacramentos da iniciação cristã, especialmente a eucaristia, e para reafirmar a veracidade dos mistérios cristãos (a presença real de Jesus no pão e no vinho) em face à fé dos judeus. Para isto, utiliza-se dos conhecimentos adquiridos previamente pelos ouvintes, do conhecimento de diversas passagens bíblicas que lhe foram ensinadas durante um ano todo. A utilização desses conhecimentos prévios criaria uma zona de desenvolvimento proximal que, partindo de verdades já aceitas, facilitaria a aceitação de verdades ainda obscuras. ${ }^{59}$

Devido a compreender o trabalho exegético e de interpretação das Escrituras como não podendo resumir-se à compreensão de um conjunto de fatos, quer a nível histórico, quer a nível literário, mas tendo como verdadeiro objetivo sua atuação de guia para nossas ações, fornecendo algo mais do que

\footnotetext{
${ }^{58}$ BRONCKART, J., Atividade de linguagem, texto e discurso, p. 225-228.

${ }^{59}$ VYGOTSKY, L. S.; LURIA, A. R.; LEONTIEV, A. N., Linguagem, Desenvolvimento e Aprendizagem, p. 18.112-115.
} 
aquilo que, num primeiro momento, os sentidos seriam capazes de captar, ${ }^{60}$ é justamente isso que se percebe na homilia de Ambrósio sobre "Os Sacramentos".

Composta por vinte e nove parágrafos, a homilia de Ambrósio de Milão coloca-se em "conjunção" a sua situação de produção, manifesta um discurso da ordem do expor. Esse discurso, no que diz respeito ao "ato de produção", apresenta-se em implicação, havendo diversos momentos nos quais o autor se dirige diretamente aos ouvintes, o que fica evidente pela expressão "Escuta", repetida oito vezes durante toda a homilia, bem como alguns dêiticos pessoais, espaciais e temporais: "mas te digo que depois da consagração já é corpo de Cristo",61 "Vês, portanto, como é eficaz a palavra de Cristo",62 "Volta comigo agora ao meu assunto" ${ }^{63}$ dentre outros.

A sequência que predomina nesta homilia é a sequência explicativa. A fase da CONSTATAÇÃO, que é a fase na qual se introduz uma ação, situação incontestável se faz evidente no primeiro parágrafo. Neste momento são apresentados fatos do Antigo Testamento e uma citação do Novo Testamento, informações sobre as quais será construída toda a argumentação precedente:

No Antigo Testamento, os sacerdotes costumavam entrar frequentemente na primeira tenda; na segunda tenda, porém, o sumo sacerdote entrava uma só vez por ano. É isso evidentemente que o apóstolo Paulo explica aos hebreus, acolhendo textos do Antigo Testamento. Na segunda tenda, havia o maná, e aí também havia a vara de Aarão, que tinha secado e depois novamente brotado, e o altar do incenso ( $\mathrm{Hb} 9,2-7) .{ }^{64}$

As fases da PROBLEMATIZAÇÃO (fase de explicitações da ordem do porquê ou do como, relacionadas a contradições do enunciado) e da RESOLUÇÃO (fase na qual são introduzidas informações complementares, capaz de resolver as contradições), aparecem sincronizadas, o que fica evidente pelas várias perguntas retóricas feitas no decorrer da homilia. $\mathrm{Na}$ grande maioria das vezes, cada parágrafo é iniciado pela apresentação de um questionamento, de uma "problematização" relativa à afirmação anterior ou à consequência resultante dela. A "resolução" ao problema levantado vem logo

${ }^{60}$ FIGUEIREDO, F. A., Curso de Teologia Patrística, p. 126-127.

${ }^{61}$ AMBRÓSIO, Sobre os Sacramentos, IV, cap. 4, §16.

62 AMBRÓSIO, Sobre os Sacramentos, IV, cap. 4, §15.

${ }^{63}$ AMBRÓSIO, Sobre os Sacramentos, IV, cap. 5, §24.

${ }^{64}$ AMBRÓSIO, Sobre os Sacramentos, IV, cap. 1, §1. 
na sequência, e para isso, são utilizados os conhecimentos previamente repassados aos fiéis, encontrados em textos do Antigo e do Novo Testamento.

Exemplos de como a sincronia dessas duas fases ocorre na homilia de Ambrósio são os parágrafos 9 a 11, nos quais, em consequência da reflexão apresentada até o momento, o leitor (ouvinte) poderia se questionar sobre a grandiosidade dos "sacramentos dos judeus"; Ambrósio, porém, se propõem a mostrar como isso não pode ser verdadeiro:

Alguém poderá perguntar: "Deus concedeu tão grande graça aos judeus, fazendo-lhes chover o maná do céu" (Ex 16,13-15). O que mais ele deu aos seus fiéis? O que mais ele deu àqueles aos quais mais prometeu?

Recebe o que digo: os mistérios dos cristãos são mais antigos do que os dos judeus e os sacramentos dos cristãos são mais divinos do que os dos judeus. De que modo? Escuta. Quando os judeus começaram a existir? Certamente desde Judá, bisneto de Abraão, ou, se queres assim entender, desde a Lei, isto é, desde que mereceram receber o direito de Deus. É, portanto, por causa do bisneto de Abraão, que foram chamados judeus no tempo do santo Moisés. Deus, então fez chover do céu o maná para os judeus que murmuravam. Mas para ti, a figura desses sacramentos veio antes, no tempo de Abraão, quando ele reuniu trezentos e dezoito servos, perseguiu os inimigos e arrancou seu neto do cativeiro. Então voltou vitorioso, e o sacerdote Melquisedec veio ao seu encontro e ofereceu pão e vinho (Gn 14,14-18). Quem tinha o pão e o vinho? Abraão não tinha. Quem os tinha? Melquisedec. É ele, portanto, o autor dos sacramentos. Quem é Melquisedec, que significa rei de justiça, rei de paz? ( $\mathrm{Hb} 7,2)$. Quem é esse rei de justiça? É possível que algum homem possa ser rei de justiça? Quem é, portanto, rei de justiça, senão a justiça de Deus? Quem é a paz de Deus, a sabedoria de Deus? (1Cor 1,30). Aquele que pode dizer: "Dou-vos a minha paz, deixo-vos a minha paz" (Jo 14,27). Portanto, de início, compreende que esses sacramentos que recebes são mais antigos do que os sacramentos que os judeus dizem ter, e que o povo cristão começou antes que o povo dos judeus começasse, nós por predestinação, eles por nome. ${ }^{65}$

A fase da CONCLUSÃO-AVALIAÇÃO se encontra a partir do parágrafo 27 e vai até o 29. Este é o momento no qual as afirmações iniciais são retomadas e ressignificadas. Pela força da argumentação apresentada na resolução dos questionamentos levantados, o fiel é levado a assumir a verdade apresentada inicialmente como carente de sentido, ao mesmo tempo em que

${ }^{65}$ AMBRÓSIO, Sobre os Sacramentos, IV, cap. 3, §9-11. 
uma nova afirmação incontestável vai sendo elaborada. Como, porém, a perspectiva metodológica adotada por Ambrósio é a de sempre se manter aberto ao mistério e de que as verdades da fé devem servir para a vida cotidiana dos fiéis, os parágrafos de conclusão apontam para a utilidade dos sacramentos dos cristãos:

Portanto, todas as vezes que o recebes, o que é que o apóstolo te diz? Todas as vezes que o recebemos, anunciamos a morte do Senhor (1Cor $11,26)$. Se (anunciamos) a morte, anunciamos a remissão dos pecados. $\mathrm{Se}$, todas as vezes que o sangue é derramado, é derramado para a remissão dos pecados, devo recebê-lo sempre, para que perdoe sempre os meus pecados. Eu que peco sempre, devo sempre ter um remédio. [...] Que o Senhor nosso Deus vos conserve a graça que vos deu e que ele se digne iluminar mais plenamente os vossos olhos que ele abriu, por seu Filho unigênito, rei e salvador, Senhor nosso Deus, pelo qual e com o qual, ele tem o louvor, a honra, a glória, a majestade, o poder, com o Espírito Santo, desde os séculos, agora e sempre, e pelos séculos dos séculos. Amém. ${ }^{66}$

Dos elementos estilísticos mais recorrentes e que evidenciam o Método Alegórico de Ambrósio, estão:

a) A linguagem informal e a tentativa de diálogo com o leitor (ouvinte), expressas pelo uso da segunda pessoa do singular e pelos verbos conjugados no imperativo afirmativo, com caráter de sugestão e/ou orientação.

b) A leitura dos textos do Antigo Testamento sempre à luz do Novo Testamento e do mistério do Cristo, no intuito de promover uma ampliação da compreensão das Escrituras, levando a uma experiência epifânica diante de fatos e narrativas que se considerava já conhecidas: "na segunda tenda havia o altar do incenso. $\mathrm{O}$ altar do incenso é aquele que costuma espalhar bom odor. Portanto, também vós sois o bom odor de Cristo, pois em vós já não existe nenhum tipo de faltas". ${ }^{67}$

c) A tentativa de inscrever o fiel como participante ativo da História da Salvação, à medida que se torna membro da comunidade cristã e tem acesso a seus mistérios: "Queres saber mediante quais palavras celestes se consagra? Escuta quais são as palavras (ditas pelo sacerdote). [...]. Repara também nos pormenores". ${ }^{68}$

${ }^{66}$ AMBRÓSIO, Sobre os Sacramentos, IV, cap. 4, §28-29.

${ }^{67}$ AMBRÓSIO, Sobre os Sacramentos, IV, cap. 1, §4.

${ }^{68}$ AMBRÓSIO, Sobre os Sacramentos, IV, cap. 5, §21.23. 


\section{Conclusão}

Espera-se que ao final deste estudo, além de um resgate da importância e atualidade do método utilizado pelos Padres da Igreja na interpretação e ensino das Escrituras, também possa ter sido possível o início de um frutuoso diálogo com o Interacionismo Sociodiscursivo (ISD), não apenas ampliando sua utilização para a esfera da Teologia e Hermenêutica Bíblica, mas também levando o Método Alegórico para o âmbito dos Estudos da Linguagem e das Teorias de Letramento.

Ao demonstrar a riqueza teórica que os métodos compartilham entre si é possível o reconhecimento de que mesmo distantes 15 séculos os Santos Padres ainda têm muito a contribuir não apenas com a Teologia, mas com a busca pela Verdade em nossa cultura, trazendo uma perspectiva viva e inovadora para os atuais estudos da linguagem - inovação que tem o ISD e demais Teorias de Letramento como seus representantes.

Ao mesmo tempo em que o estandarte da inovação pode ser empunhado, esperamos que este estudo seja capaz de levar os atuais pesquisadores a uma posição de humildade frente as práticas pedagógicas da antiguidade cristã e, quem sabe, ao reconhecimento de que muitos dos ganhos e avanços de hoje já haviam sido vislumbrados e postos em práticas por esses primeiros mestres.

\section{Referências bibliográficas}

ABBAGnANO, N. Alegoria. In: ABBAGNANO, N. (Ed.). Dicionário de Filosofia. São Paulo: Martins Fontes, 2007. p. 23.

ABBAGnANO, N. Patrística. In: ABBAGNANO, N. (Ed.). Dicionário de Filosofia. São Paulo: Martins Fontes, 2007. p. 746.

AGOSTINHO. A Doutrina Cristã. São Paulo: Paulus, 2011. (Patrística, 17).

AGOSTINHO. Confissões. São Paulo: Paulus, 2009. (Patrística, 10).

AMBRÓSIO. Examerão. São Paulo: Paulus, 2010. (Patrística, 26).

AMBRÓSIO. Sobre os Sacramentos. São Paulo: Paulus, 2010. (Patrística, 5).

BAKHTIN, M. Estética da Criação Verbal. São Paulo: Martins Fontes, 1997. BASÍLIO DE CESAREIA. Homilia sobre Lucas 12, Homilias sobre a origem do homem, Tratado sobre o Espírito Santo. São Paulo: Paulus, 2012. (Patrística, 12). 
BENTO XVI, PP. Os Padres da Igreja: de Clemente de Roma a Santo Agostinho. São Paulo: Cultrix, 2010.

BOGAZ, A. S.; COUTO, M. A.; HANSEN, J. H. Patrística, caminhos da tradição cristã. São Paulo: Paulus, 2008.

BOROBIO, D. Pastoral de los sacramentos. Salamanca: Secretariado Trinitário, 1996.

BRONCKART, J.-P. Atividade de linguagem, texto e discurso: por um interacionismo sociodiscursivo. São Paulo: Educ, 1999.

CLEMENTE DE ALEJANDRÍA. EI Pedagogo. Madrid: Editorial Gredos, 1988. BÍBLIA Sagrada. 2.ed. São Paulo: Loyola, 2002.

COMBY, J. Para ler a História da Igreja. 3.ed. São Paulo: Loyola, 2001. v.I. CONCÍLIO VATICANO I. Constituição Dogmática Dei Filius. Disponível em: $\quad<$ http://www.vatican.va/archive/hist_councils/i-vaticancouncil/documents/vat-i_const_18700424_dei-filius_it.html $>$. Acesso em: 01 set. 2019.

DROBNER, H. R. Manual de Patrología. 2.ed. Barcelona: Herder, 1999.

FRANCISCO, PP. Exortação Apostólica Evangelii Gaudium. Disponível em: $<$ http://www.vatican.va/content/francesco/pt/apost_exhortations/documents/p apa-francesco_esortazione-ap_20131124_evangelii-gaudium.html $>$. Acesso em: 07 set. $20 \overline{19}$.

FIGUEIREDO, F. A. Curso de Teologia Patrística. Petrópolis: Vozes, 1990. v.3. FIGUEIREDO, F. A. La Vita de la Iglesia Primitiva - Curso de Teología Patrística. Bogotá: CELAM, 1991.

FILÓN DE ALEJANDRÍA. Sobre la migración de Abraham. In: FILÓN DE ALEJANDRÍA. Obras Completas. Buenos Aires: Acervo Cultural, 1976. p. 206-243. t. II.

FILÓN DE ALEJANDRÍA. Sobre las habituales intrigas de lo peor contra lo mejor. In: FILÓN DE ALEJANDRÍA. Obras Completas. Buenos Aires: Acervo Cultural, 1976. p. 203-231. t. I.

GABEL, J. B.; WHEELER, C. B. A Bíblia como Literatura. São Paulo: Loyola, 2003. 
GARGANO, I. A metodologia exegética dos Padres. In: YOFRE-SIMIAN, H. (Org.). Metodologia do Antigo Testamento. São Paulo: Loyola, 2015. p. 179202. (Bíblica Loyola, 28).

GREGÓGIO MAGNO. Regra Pastoral. São Paulo: Paulus, 2010. (Patrística 28). GUNNEWEG, A. H. J. Hermenêutica do Antigo Testamento. São Leopoldo: Sinodal, 2003.

JAEGER, W. Cristianismo Primitivo e Paideia Grega. Santo André: Academia Cristã, 2014.

ORÍGENES. Tratado sobre os Princípios. São Paulo: Paulus, 2017. (Patrística, 30).

ORLANDI, E. P. O que é linguística. São Paulo: Brasiliense, 2005.

ORLANDIS, J. Historia de la Iglesia. Madrid: Ediciones Rialp, 2014.

PADOVESE, L. Introdução à Teologia Patrística. São Paulo: Loyola, 2004.

QUASTEN, J. Patrología - Hasta el concilio de Nicea. 3.ed. Madrid: BAC, 1978. v.1.

QUASTEN, J. Patrología - La edad de oro de la literatura patrística latina. 3.ed. Madrid: BAC, 1981. v. 3.

REALE, G.; ANTISERE, D. História da Filosofia. São Paulo: Paulinas, 1990. v.1. ROQUETTE, J. I.; FONSECA, J. Homilia. In: ROQUETTE, J. I.; FONSECA, J. (Eds.). Diccionario dos synonymos poeticos e de epithetos da lingua portugueza. Pariz: Aillaud, Guillard e Cia, 1863. p. 372.

SCHNEUWLY, B.; DOLZ, J. Gêneros orais e escritos na escola. Campinas: Mercado das Letras, 2011.

SCHÜLER, A. Homilia. In: SCHÜLER, A. (Ed.). Dicionário Enciclopédico de Teologia. Canoas: Ulbra, 2002. p. 236.

SCHÜLER, A. Sermão. In: SCHÜLER, A. (Ed.). Dicionário Enciclopédico de Teologia. Canoas: Ulbra, 2002. p. 423.

SIMONETTI, M.; PRINZIVALLI, E. Storia della letteratura cristiana antica. Bologna: Edizioni Dehoniane Bologna, 2011.

TABORDA, F. Nas fontes da vida cristã. São Paulo: Loyola, 2001. 
VYGOTSKY, L. S. Pensamento e Linguagem. São Paulo: Ed. Ridendo Castigat Mores, 2002. Disponível em: <http://www2.uefs.br/filosofiabv/pdfs/vygotsky_01.pdf $>$. Acesso em: 07 set. 2019.

VYGOTSKY, L. S.; LURIA, A. R.; LEONTIEV, A. N. Linguagem, Desenvolvimento e Aprendizagem. São Paulo: Icone, 2010.

João Carlos Domingues dos Santos Rodrigues Doutorando em Teologia pela Pontifícia Universidade Católica do Paraná Londrina / PR - Brasil E-mail: joannescarlus@hotmail.com

Recebido em: 30/03/2020

Aprovado em: 27/10/2020 